International Journal of Engineering Research and Development

Cilt/Volume:9

Sayı/Issue:3

Aralık/December 2017

https://doi.org/ 10.29137/umagd.350831

\title{
Stratigraphy of The Region Erbaa (Tokat)
}

\begin{tabular}{|c|c|c|}
\hline \multicolumn{3}{|c|}{ Özlem TOPRAK ${ }^{* 1}$, Mehmet AKYAZI ${ }^{2}$} \\
\hline \multicolumn{3}{|c|}{$\begin{array}{c}{ }^{1} \text { Gaziosmanpaşa University, Tokat Vocational High School } \\
{ }^{2} \text { Cumhuriyet University, Faculty of Engineering, }\end{array}$} \\
\hline Bașvuru/Received: 08/10/2017 & & Son Versiyon/Final Version: 26/12/2017 \\
\hline
\end{tabular}

\begin{abstract}
The Permo-Triassic basement rocks form the basis of the study area, which is located on the North Anatolian Fault and immediate vicinity of the Erbaa District on the north. The primary covering units overlying the basement rocks consist of a thick deposit, deposited in the depression in front of the Eurasian continent during the Liassic-Upper Eocene time interval. The first cover units, unconformably overlying the basic rocks, are overlaid by conglomerate, sandstone, mudstone, marl and oolitic limestones and Lower-Middle Jurassic rocks composed of volcano-clastic rocks, Upper Jurassic-Lower Cretaceous aged neritic and pelagic clayey limestones, the Santonian-Campanian aged sedimentary rocks in the pyroclastic character accompanied by the volcanicvolcanosedimentary rocks formed by the submarine volcanic activity in the Upper Cenomanian, Maestrichtian-Paleocene sandy limestones, Lower-Middle Eocene conglomerate, volcanogenic sandstone, sandy limestone and nummulites limestones and Upper Eocene basalt, pillow lavas, andesite, tuff, tuffite, aglomera, sandstone and siltstone intercalation unconformably. Secondary cover units, composed of loosely adhered conglomerates and sandstones that collapse during terrestrial atmospheric conditions in depressions formed along the North Anatolian Fault zone, are covered by the Quaternary aged alluvium, slope rubble and deposit cones, which constitute the youngest units of the study area.
\end{abstract}

\section{Key Words}

"Erbaa, General Geology, Stratigraphy" 


\section{INTRODUCTION}

The survey area covers d1, d2, d3 of the Tokat G37 Paftas which is located on the North Anatolian Fault and just north of the Erbaa District and its immediate surroundings.

Numerous different geological studies have been carried out in the study area, especially with tectonic contents. Among these studies, (Akyazı \& Tunç, 1992), (Aktimur et al., 1992), (Alp, 1972), (Ambraseys , 1970), (Ambraseys , 1971), (Arpat \& Saroğlu , 1975), (Barka et al. , 2000), (Blumentha , 1950), (Kavak et al. , 2006), (Özcan et al. , 1980), (Öztürk, 1979), (Toprak, 2014), (Serdar et al., 1975), (Sezen et al., 1975) and (Yoldaş et al., 1985) available.

For the purpose of this study, detailed geological-paleontological-biostratigraphic features of the units in the target area will be revealed and the geological and stratigraphic location of the study area will be tried to be interpreted.
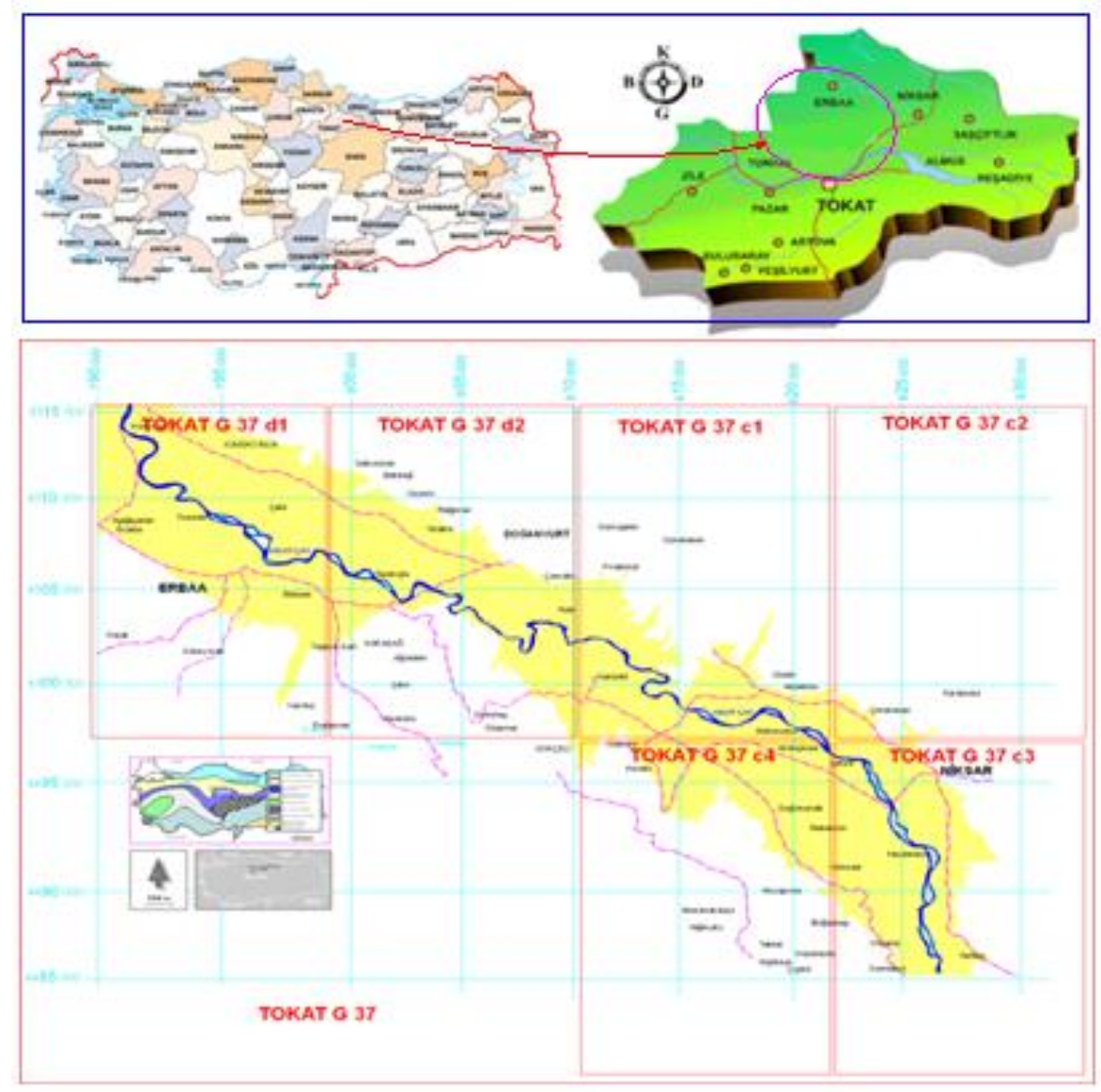

Figure 1. Location map of the study area

\section{GENERAL GEOLOGY OF ERBAA (TOKAT) REGION}

The Permo-Triassic basement rocks form the base of the study area, which is located on the North Anatolian Fault and just north of the Erbaa District and its immediate surroundings. The first covering units overlying the basement rocks consist of a thick deposit deposited in the depression in front of the Eurasian continent during the Liassic-Upper Eocene time interval. Upper JuraLower Cretaceous aged neritic and pelagic clayey limestones, Upper Cenomanian limestones, Upper Cenozoic limestones, Upper Cenozoic limestones, Upper Cenozoic limestones, Maastrichtian-Paleocene sandy limestones, Lower-Middle Eocene aged conglomerate, volcanogenic sandstone, sandy limestone and nummulitesite limestones and basalts of the Upper Eocene age, with the volcanic-volcanosedimentary rocks formed due to submarine volcanic activity, pillow lavas, andesite, tuff, tuffite, agglomerate, sandstone and siltstone alternation. Second cover units composed of loosely adhered conglomerates and sandstones that collapse during the North Anatolian Fault zone and in terrestrial atmospheric conditions are covered by the Quaternary aged alluvium, slope rubble and deposit cones, which constitute the youngest unit of the study (Toprak, 2014). 


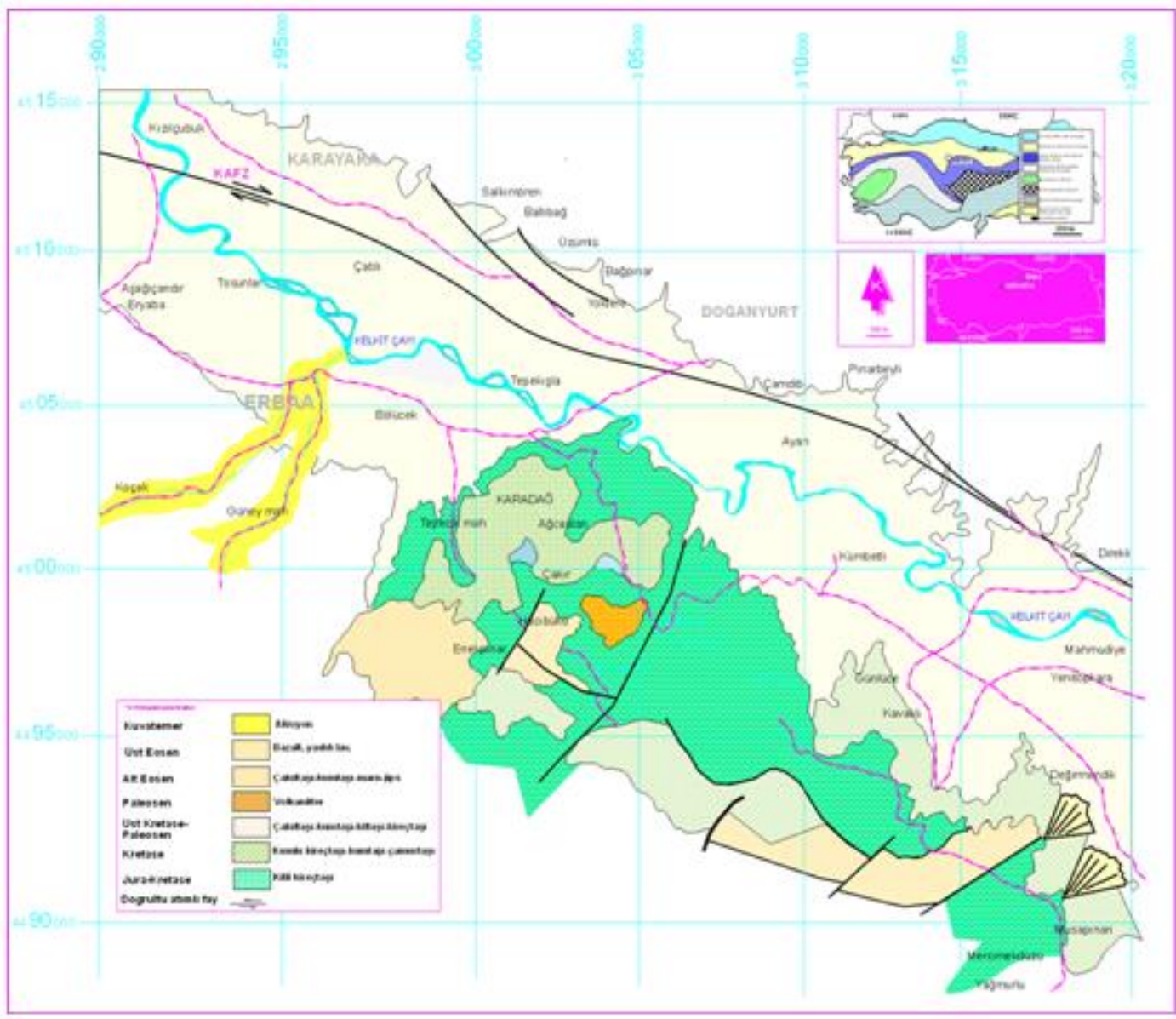

Figure 2. The geological map of Erbaa(Tokat) region

\section{STATIGRAPHY OF ERBAA(TOKAT) REGION}

Permo-Triassic:The basement rocks bearing low-grade metamorphic rocks are composed of metamorphic matrix composed of quartzite, calcschist, epidote schist, milonitgniss, micaschist, metaclastic and metacvar sandstones and recrystallized limestone / limestone blocks floating in this matrix (Akyazı \& Tunç, 1992). Studies on thin sections of the samples taken from crystallized limestones show that the Schwagerina sp., Neoschwagerina sp. and Polydiexodina sp. Fossils were identified. For this reason, the age of crystallized limestones was accepted as Permian in this study. Considering that the Lower-Middle Jurassic and Upper Jura-Lower Cretaceous units, which are located on the metamorphic matrix with Permian aged blocks, do not undergo metamorphism, the metamorphic rocks are PermoTriassic and have metamorphism before the Upper Jurassic.

Thickness cannot be clearly defined in the survey area but it can be 300-350 m thick. The unit is located in the south of the Niksar district in the south of the study area and the south of the Erbaa district in the west (Figure 3).

Lower-Middle Jura: It begins with polygenic conglomerates containing metasedimanter-metavolcanic pebbles composed of limestone gravels of calcschist, gneiss, muskovitshist, marble and Permian aged with yellowish red colored carbonate cement. It is formed by dark gray-blackish colored, fine to medium, coarsely grained, to mediumbedded sandstone with tightly bonded carbonates. At the top of the unit a thin limestone band containing mudstone plaster was observed. Dark colored, thick bedded aglomera, andesitic lava flows and pillow lavas and light cream colored, thin-medium bedded tuffs were added in the sediments of pebbles, sandstones and thin mudstones above, depending on submarine volcanic activity parallel to sedimentation. 
Within the area of the sandstones and limestones of the study area, the thickness of which is determined as 150-200 m; Andersenolina elongata (Leupold), Pseudocyclammina liasica Hottinger, Involutina sp., Triloculina sp., Quinqueloculina sp., Phylloceras sp. and Pentacrinus sp. Fossils were identified. According to these fossils that have been determined, the Lower-Middle Jurassic age is given (Figure 3).

In the central part of the study area, the unit which confronts between the Direkli and the Kümbetli Villages; agglomeratic levels, andesitic lava flows and pillow lavas, although occasionally, show that the unit under which the submarine volcanism is active has collapsed.

Upper Jura-Lower Cretaceous:The unit begins with medium-thick bedded sandy sparitic sandstones at the lower levels and continues upward with the Titonik facies tempered limestones in the micro-biophysics of calpionellibiomicrite containing claystone and mudstone levels.

Oxfordian-Kimmericy:Lower levels of limestones in fossiliferous oopelsparitmicrofibres, unconformably overlying the Lower-Middle Jurassic units, are composed of pozzolithic and pseudolithic inclusions of chert layers and lenses, grayish, creamy and occasionally pinkish, occasionally dark gray, beige colored, medium-thick layered, with a massive appearance in places and a cracked structure.

Within the unit, Clypeinajura Favre, Oxophene-kimmericyen age, Clypeina jurassica Favre, Protopeneroplis striata Weynschenk, Globuligerina sp., Apthycus sp. and Pseudocyclammina sp. Fossils were identified. The thickness of the unit is measured as $160 \mathrm{~m}$ in the survey area.

Tithonian-Berriyasiyen: Mesoendothyra sp., Pseudotextularia sp., Triloculina sp., Saccacoma sp., in the clayey limestones with gray-colored, fossiliferous biosparitemicrobiofacies, which are intercalated on the Oxfordian and Quinqueloculina sp. Fossils were identified. Depending on the fossil content and stratigraphic location, it is thought that these levels of the unit may be Lower Titanian.

The unit continues upward with gray-dark gray colored clayey limestones with the Titonik facies in the microbiophysical calpionibiomicrite, including claystone-mudstone levels. The clayey pelagic limestones at these levels of the unit contain Titonian-Berriyan age; Calpionellopsis simplex (Colom), Calpionellopsis oblonga (Cadisch), Radiolaria and spongel spicules were detected in Tintinnopsella carpathica (Murgeanui ve Filipescu), Crassicollaria intermedia (Durand Delga), Crassicolaria parvula Remane, Calpionella alpina Lorenz, Calpionella elliptica Cadisch, Remaniella cadischiana (Colom). Studies on Calpionel biostratigraphy have identified and identified Crassicollaria intermedia, Calpionellaalpina, Calpionellaelliptice, Calpionellosis simplex-Calpionellopsis oblanga calpionel biozones in the unit of the Titonic Facies.

The Upper Jurassic-Lower Cretaceous units measuring $455 \mathrm{~m}$ in thickness in the study area are exposed in the central Montenegro region of the study area and indicate the conditions of pelagic environment sedimentation at the upper levels while the basal neritic environment features are shown.

It can be said that the lower levels are thick-bedded, and the upper levels are composed of abundant cherts, micritic limestone, clayey and muddy limestone lithologies, and this unit has collapsed in a deepening marine environment.

Upper Cretaceous:Starting with reddish colored, tightly adherent conglomerates and upwardly gray, brown colored, thin-medium bedded, carbonate-cemented sandstones; marble-mudstone with variegated colored carbonate marlmudstones and their partially metamorphosed derivatives and recrystallized limestones, and the volcanic intercalated sandstone-marl-limestone alternation developed in flysch facies with hard, fragile textured limestones in clay, globotruncanized biomicrite microbiophysi are available. The measurable thickness of the unit is measured as $325 \mathrm{~m}$. 
Cenomanian-Coniacian:It is observed that the lower levels of conglomerate, sandstone, marl mudstone and their partially metamorphosed derivatives and sedimentary rocks composed of crystallized pelagic limestones are accompanied by volcanic gneisses consisting of volcanic pebble breccias and andesites and tuffites. The accompanying volcanic and volcanosedimentary rocks of the crushed sedimentary rocks indicate the volcanic activity in the Upper Cretaceous region. Fossils of Paraeoglobotruncanita gibba Klaus, Dicarinella imbricata (Mornod), Helvetoglobotruncana helvetica (Bolli), Marginotruncanita sigali (Reichel), Marginotruncana pseudolinneiana Pessagno and Whiteinella sp. were found in the Cenomanian-Koniasian aged levels of carbonate marls and limestones at lower levels of the unit (Figure 3).

Santonian-Campanian: Globotruncana biolochiibiomicritis consists of hard, fragile textured limestones in the microbiobiophysi, and volcanic intercalated sandstone-limestone-marl intercalations in the upper levels. The unit of Santoian-Campanian age, Globotruncana bulloides Vogler, Globotruncanita elevata (Brotzen), Globotruncana lapparenti lapparenti Brotzen, Rosita fornicata (Plummer), Globotruncana sp. planktonic foraminifera were detected.

Maastrichtian:The yellowish-colored, thin-medium bedded fossiliferous biosparite consists of sandy limestones with microbiofaciesty developed. Within the unit, the foraminifera of Sirelina orduensis İnan, Orbitoides medius (D'archiac), Hellenocyclina beotica Reichel, Siderolites calcitrapoides Lamarck, Omphalocyclus macroparus (Lamarck) and Discocyclina sp., bentik were determined. According to the determined fossils, this unit, which is determined to have collapsed at the age of Cenomanian-Maastrichtian age, has a fault-controlled area around NW-SE direction to the south of the study area (Figure 3).

Paleocene:The unit, which consists of fossiliferous biosparitemicrobiophase with dark gray colored medium-bedded, hard-textured, bi-directional joints and composed of slightly sandy limestone, has a thickness of approximately $220 \mathrm{~m}$. In the unit, İdalina sinjarica Grimsdale, Missisippina binkhorsti Reuss and Rotalia trochidiformis fossils, which gave Paleocene age, were determined. Unit-owned exposures offer a wide range of fault-controlled landscapes starting from the south-eastern part of the Erbaa county and continuing along the southern coast of the Kelkit River to the southeast.

Lower-Middle Eocene:The units which are very wide spreading in the study area are composed of grayish and somewhat variegated colored medium to thin bedded units in the upper levels with yellowish brown colored conglomerate, pebbly sandstone, sandstone, mudstone, claystone, marl and units in turbiditic flysch facies, consists of shallow marine limestone, which is locally laminated mostly decayed.

Within the unit, Nurdanella boluensis Özgen Alveolina stercusmaris Mayer-Eymar, Asterigerina rotula Kaufmann, Alveolina sp., Assilina sp., Nummulites sp., Aktinocyclina sp. and Valvulina sp. as well as benthic foraminifera like Turritella sp. and Ostrea sp. Many macrofossils belonging to Gastropoda, Lamellibranchiata, Brachioopoda branches which were not defined on the basis of breed were observed.

The conglomerates at the base of the unit are variegated colored, poor-medium sized, composed of pebbles, limestone, metamorphic rock fragments and quartzites. The conglomerates have a gray, yellowish-brown colored, bi-directional sandstone with fine-to-medium bedding.

The mudstone levels of the unit are gray, yellowish-reddish colored, soft-textured structure and it is lined with yellow, greenish, fine claystones in places. In the upper levels, the unit is accompanied by mudstone-sandstone alternations, white-cream colored, thin-medium bedded marls.

The highest levels of the unit are shallow marine limestones with grayish, white, abundant Nummulitic, massive textured, thick bedded, some levels brecciated, Nummulitic biosparit microbiophysical features. The presence of agglomerates composed of volcanic gravels and blocks, which are generally found in a matrix of volcanic materials, is an indication of the intensification of volcanism towards the end of the Middle Eocene. 
The gravels forming the unit are derived from basalt, andesite and metamorphic rocks. This lithology, which consists of dark colored pebbles in quite different sizes, is rarely accompanied by sandstones, mudstones and clayey veins and coal veins in some regions.

Tuffs, which form a matrix of the agglomeratic unit where massive-looking basalts are also observed, and which are observed as interlayer in places, are observed as grayish white colored, massive, thick layers.

Upper Eocene:It consists of dark agglomerate, volcanogenic sandstone, basalt, andesite, tuff, tuffite and sandstonesiltstone intercalated volcanic rocks and dark gray-black column basalts and hard-textured andesites that cut them in dykes. Considering the stratigraphic location of the unit, it is accepted that it may be Upper Eocene aged (Aktimur et al., 1992).Starting from the eastern Niksarcounty to the north of the study area, the width of the unit which measures a wide area extending to the northwest of Doğanyurt is $180 \mathrm{~m}$.

Miocene-Pliocene:The second cover units that collapsed in the depressions along the North Anatolian Fault zone and in the terrestrial environment consist of loose and / or unconfigured conglomerate-sandstone-claystone alternations and travertines with mudstone, gypsum interbeds in general and unconformably overlapped units of all self-aged units.

The unit, which is in deteriorated construction and presents a low relief morphology, is somewhat thin-walled and often looks like a conglomerate of volcanic material, carbonate-cemented matrix, surrounded by gravels of varying sizes.

Green-brown, cross-bedded, pebbly sandstones and red colored mudstone alternations are observed in the unit, which are products of a stream environment with seasonal regime change. River channel fill and meander river sediments are located on fine-grained flood plain deposits. Consistent with all these lithologies, there are travertines that offer thinmedium strata.

Within the unit which is assumed to be Oligo-Miocene-Piliocene age, giving the fossil content and the stratigraphic position, which is the Erbaa district and south of Gökçeli, Ostracoda sp. was detected and the approximate thickness of the unit in the study area is $150 \mathrm{~m}$.

Quaternary:The youngest sediments of the study area are alluviums containing gravel-small pebbles. The alluviums are exposed to an ever-expanding area of Kelkit vineyard, north and south, from the Erbaa and Niksar districts. During the Kelkit valley, especially in the flood areas in the south and north, red limestone, radiolarite and loose textured conglomerates containing pebbles derived from metamorphic rocks and gravelly, sandy and clayey materials. Alluviums come in different grain sizes derived from various units in the world and do not show continuity in the lateral and vertical directions.

In the study area, Quaternary elderly units are composed of detritic and / or poorly fixed detritic units. These units, which characterize various sub-environments of the terrestrial environment, are observed as alluvial and kolivial specks in the central parts of the study area and in the broken parts of the formation in the upper part and in the physical comminution products, The skirt rashes in the region, the accumulation cones, and the streamside utensils are detritics that have been found in the Quaternary. The Kelkit River valley and the current bed contain the current Quaternary sediments which are composed of river equipme 


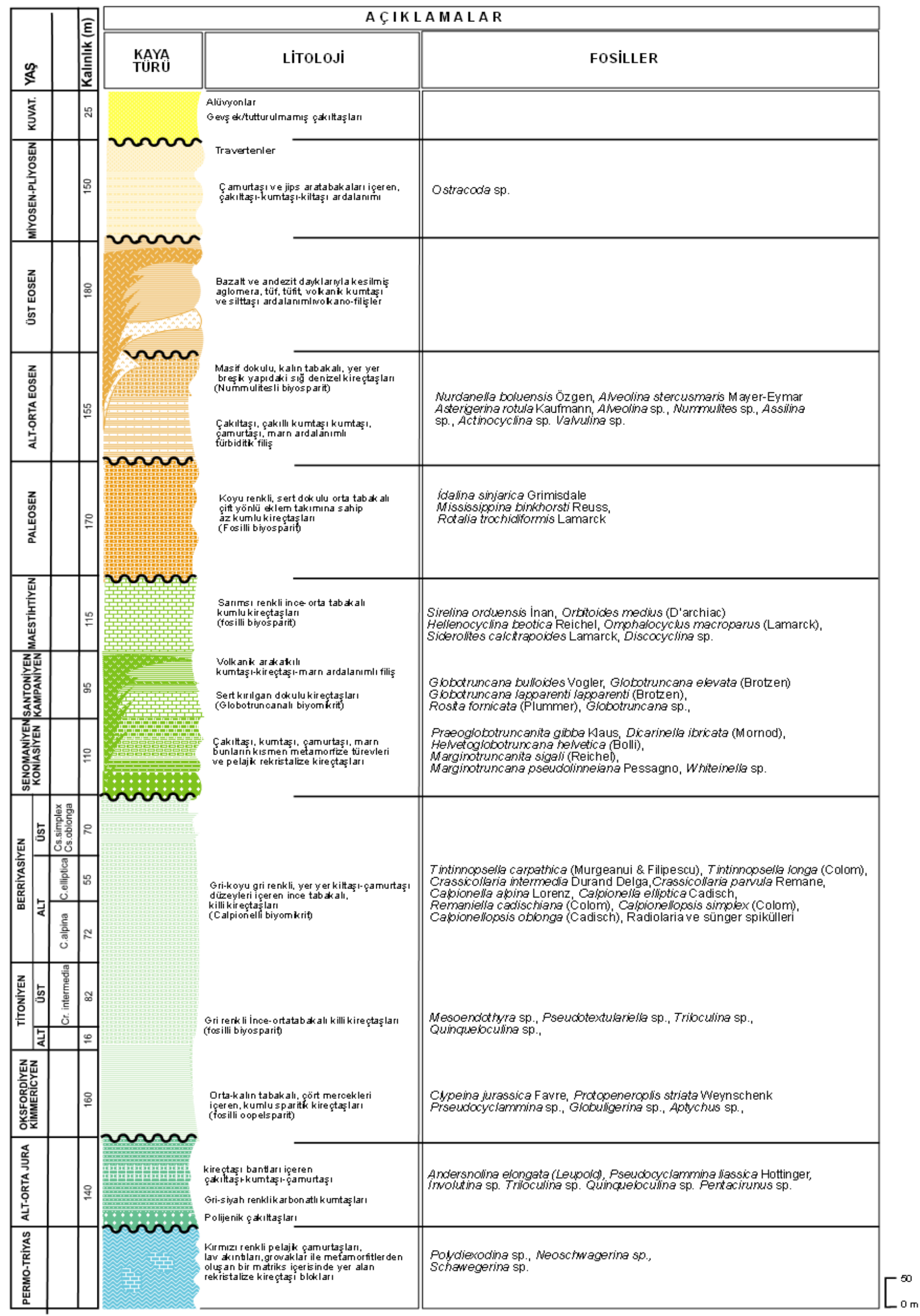

Figure 3. The generalized stratigraphic section of Erbaa(Tokat) region 


\section{ERBAA TERRITORY MEASURED STRATIGRAPHY SECTIONS}

4.1. Çakır Measured Stratigraphic Section:This section taken from the east of the Cakir Village in the southeast of Erbaa District located in the G37 d1 Paftas in the study area covering certain parts of the Tokat G 37 Paftas and taken to the southwest, is taken at 802950 latitude, 4500100 longitude start and 802100 latitude 449696 longitude finish The coordinates are approximately $1500 \mathrm{~m}$ in the direction of SW. A total of $286 \mathrm{~m}$ thickness was measured and 46 specimens were collected (Figure $4)$.

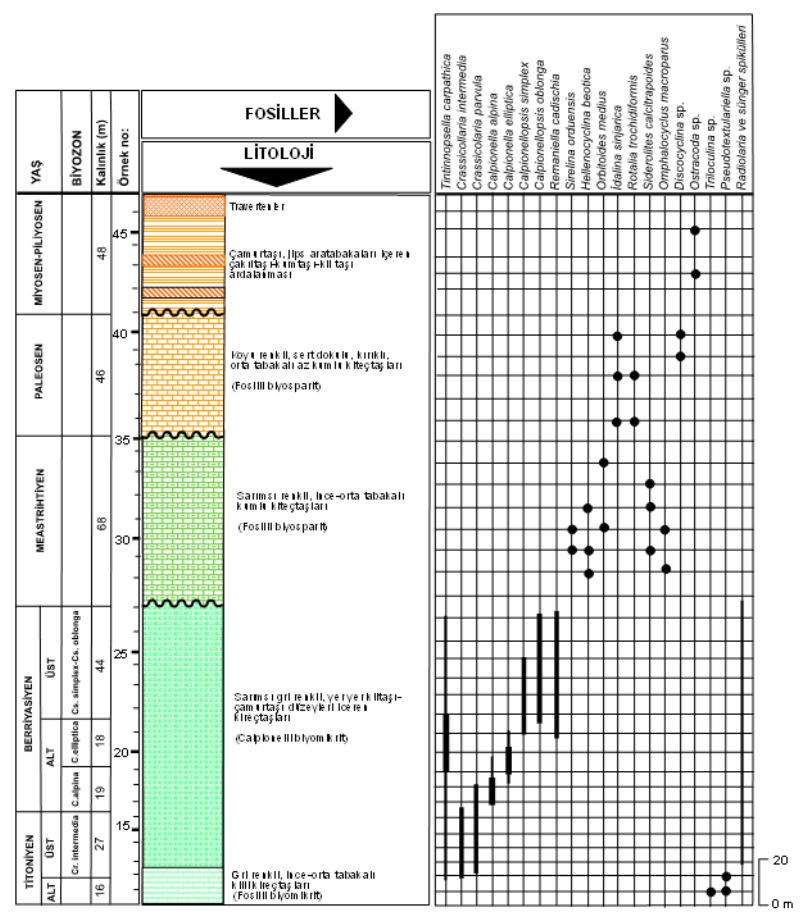

Figure 4. Çakır measured stratigraphic section.

4.2. EnekpınarMeasured Stratigraphic Section: This section, taken from the north of Enekpınar to the south-east of Erbaa District in the G37 d1 Paftas in the study area covering certain parts of Tokat G 37 Paftas, is taken from west to southwest, 799 200 latitude, 4499150 longitude start and 798500 latitude 4498800 between the longitude end coordinates, is about $1000 \mathrm{~m}$ in the direction of SW. A total of $667 \mathrm{~m}$ thickness was measured and 64 specimens were collected (Figure 5).

4.3. İverönü Measured Stratigraphic Section This section, which is located in the area G37 d1 in the study area covering certain parts of the Tokat G37 Paftas, is taken from west to northwest of the Inverönü northeastern southeast of the Erbaa District, 7,700 latitude, 4501400 longitude start and 797300 latitude 4502100 longitude end The coordinates are approximately $1840 \mathrm{~m}$ in the direction of the NW. A total of $665 \mathrm{~m}$ thickness was measured in this section and 84 specimens were collected (Figure 6). 


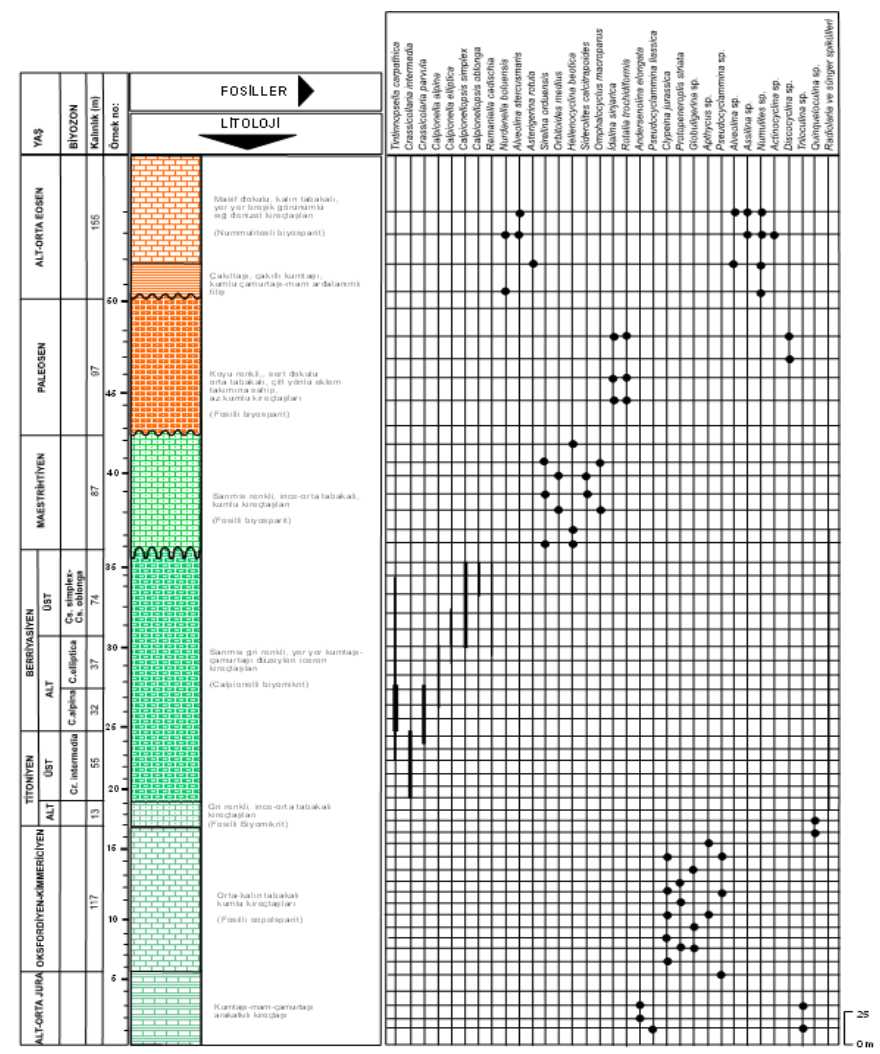

Figure 5. Enekpinar measured stratigraphic section.

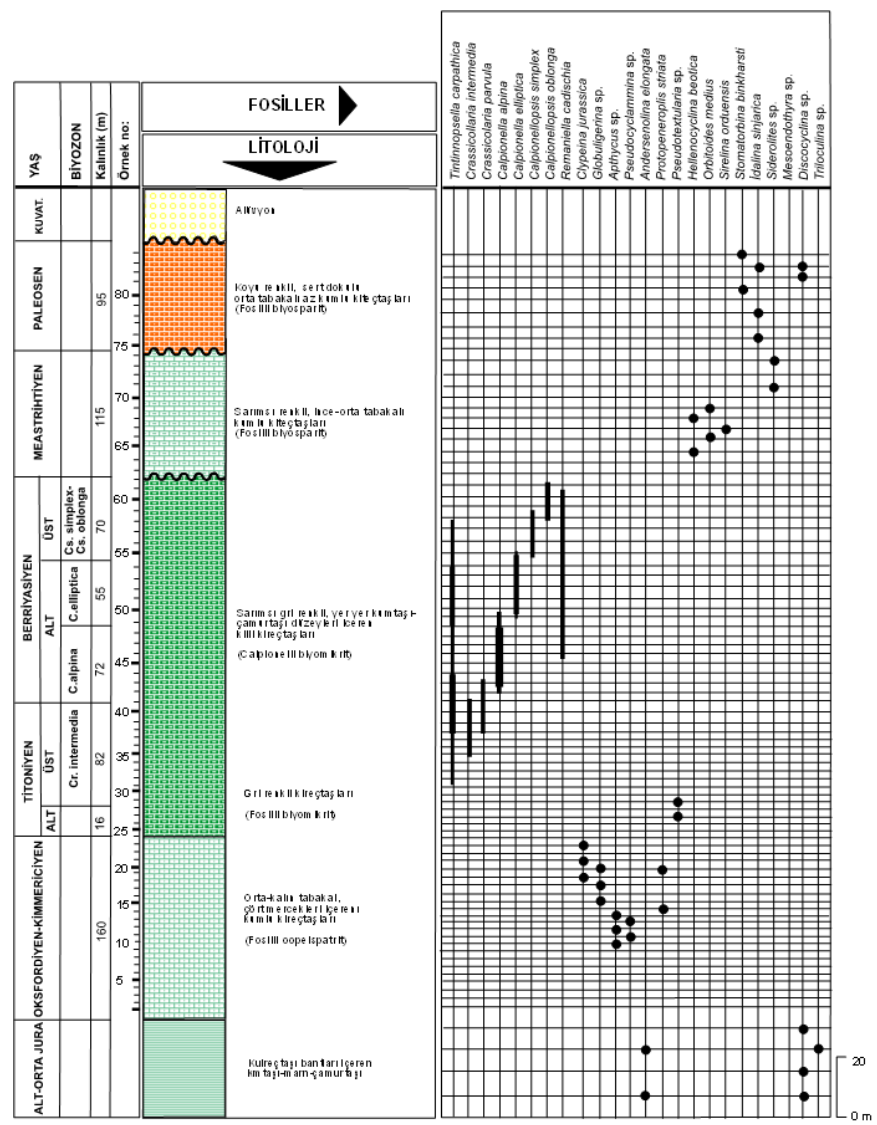

Figure 6. İverönü measured stratigraphic section. 

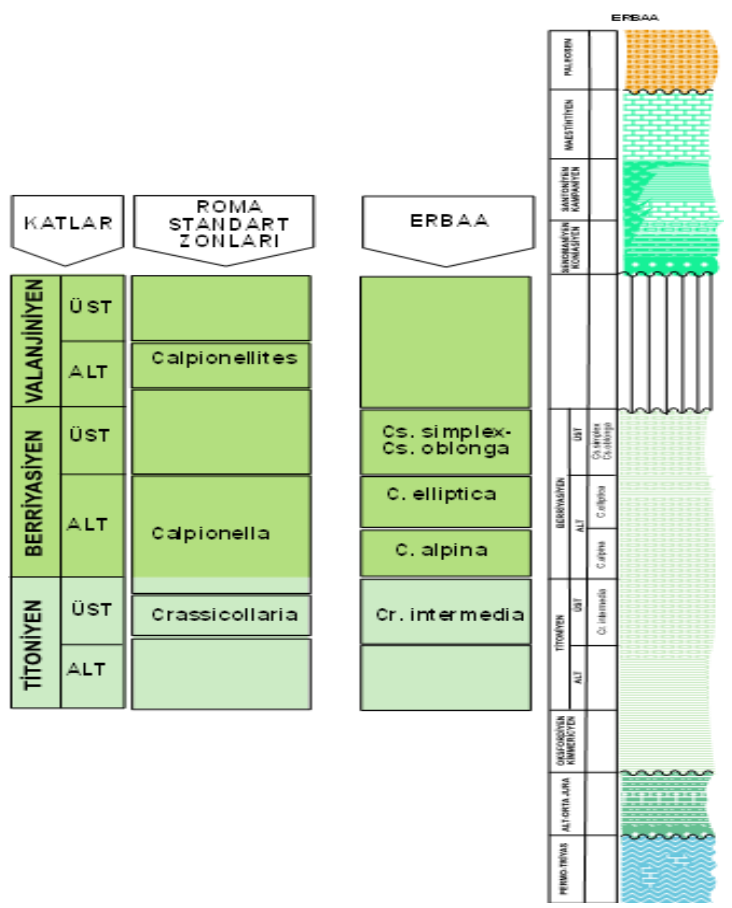

Figure 7. Detected biozones were compared to the Roman Standard Zone

\section{CONCLUSIONS}

- Geological, stratigraphic, paleontologic and biostratigraphic features of the Upper Mesozoic region have been tried to be revealed in this study, which was carried out in certain parts of Tokat H37 d1, d2 and d3 dated to 1 / 25.000 in Erbaa (Tokat) region.

- In the detailed paleontologic and biostratigraphic studies on rock samples taken systematically from sites with abundant titanic facies and Calpionel abundance, resulting in the formation of Tintinnopsella carpathica (Murgeanui ve Filipescu), Crassicollaria intermedia (Durand Delga), Crassicolaria parvula Remane, Calpionella alpina Lorenz, Calpionella elliptica Cadisch, Remaniella cadischiana (Colom), Calpionellopsis simplex (Colom), Calpionellopsis oblonga (Cadisch), 5 calpionel species and 8 species belonging to these species were identified and systematized.

- In biostratigraphic investigations of the late Titonian-Early Valanjinian aged, titanic facies developed calpionelli and radiolarialbiomicriticmicrobiophysical limestones revealed four calpionelbiozones, Crassicollaria intermedia, Calpionella alpina, Calpionella elliptica, Calpionellopsis simplex-Calpionellopsis oblonga.

- The detected biozones were compared to the Roman Standard Zone and the Crassicollaria intermedia-Calpionella zone boundary was observed to be incompatible with the Roman Standard Zone boundary.

- It is observed that the upper limit of the Calpionellopsis zone in the Erbaa region, which is located in the east of the Central Pontides, does not correspond to the Roman Standard Zone boundary.

- It is determined that the sequence of the Titonic facies in the region is missing from the top.

- Upper Jurassic-Lower Cretaceous aged limestones, which are located in the Pontide basin, are mostly found to be rich in titonic facies and rich in calpionel content.

- Although the Upper Jurassic-Lower Cretaceous aged limestones that appear on the Pontide basin are usually composed of thin-bedded micritic limestones with the formation of titonic facies, it is observed that the entire does not include Calpionel. This is a sign that the calpions are locally provincial, although not real.

\section{REFERENCES}

Akyazı, M. ve Tunç, M. (1992). Zile (Tokat) Yöresinin Stratigrafisi. TJK Bülteni, C. 35/2. s.36

Aktimur, H. T., Ateş, Ş., Yurdakul, M.E., Tekirli, M.E., ve Keçer, M., (1992), Niksar-Erbaa ve Destek Dolayının Jeolojisi. MTA Dergisi 114, 25-36, 
Alp, D. (1972) Amasya yöresinin jeolojisi. İ.Ü. Fen Fakültesi

Monografileri, Sayı; 22, $10 \mathrm{~s}$.

Ambraseys N.N. (1970): Some characteristics features of the Anatolian fault zone. Tectonophysics 9, $143-165$.

Ambraseys N.N. (1971): On the value of historical records of earthquakes. Nature 232, 375-379.

Arpat, E. Şaroğlu, F. 1975. Türkiye’deki bazı önemli genç tektonik olaylar. Türkiye Jeoloji Kurumu Bülteni, 18/1, 91-101.

Barka, A.A., Cohen, H., Aky.Z, S. \& Watchorn, F. (2000). Tectonic evolution of the Niksar and Tasova-Erbaa pull-apart basins, North Anatolian fault zone: their significance for the motion of the Anatolian block. Tectonophysics 322, $243-264$.

BlumenthaL, M.M. 1950. Beitr.ge zur Geologie des landschaften am Mittleren und unteren Yeşil Irmak (Tokat, Amasya, Havza, Erbaa,Niksar). Mineral Research and Exploration Institute of Turkey (MTA) Special Publication D 4, 153 p.

Kavak, Sezen, F. Koçbulut, O. Tatar, H. Gürsoy, B.L. Mesci,K.S.Kavak, Z. Akpınar, A. Polat, G. Kanaat veH.T. Demirel, 2006, Esençay Fayı'nın Erbaa güney batısı ve Niksar güneyindeki bölümünün jeomorfolojik özellikleri, 2006, ATAG 10. Toplantısı Bildiri Özleri Kitapçı̆̆ı, s.74.

Serdar, H.S., Yarman, M. Kazdal, R.A. ve Seymen, İ. (1975) Kelkit vadisi kesiminde Kuzey Anadolu fayzonunun tektonik özelliği, Doktora Tezi, İ.T.Ü. Maden Fakültesi Yayınları 192 s.

Sezen, F. Koçbulut, O. Tatar, H. Gürsoy, B.L. Mesci,K.S.Kavak, Z. Akpınar, A. Polat, G. Kanaat ve H.T. Demirel, 2006, Esençay Fayı'nın Erbaa güneybatısı ve Niksar güneyindeki bölümünün jeomorfolojik özellikleri, 2006, ATAG 10. Toplantısı Bildiri Özleri Kitapçı̆̆ı , s.74.

Özcan, A., Erkan, A., Keskin, A,, Keskin, E., Oral, A., Özer, S.,Sümengen, M. ve Tekeli, O. (1980) Kuzey Anadolu Fayı ile Kırşehir Masifi arasının temel jeolojisi: MTA Enst. Rapor No: 6722, 139 s. (yayımlanmamış).

Öztürk, A., 1979. Ladik-Destek yöresinin stratigrafisi: TJ.K, Bült., 22, $27,34$.

Toprak, Ö., (2014). Batı-Orta Karadenizde yüzeyleyen Jura-Kretase yüzleklerinin stratigrafisi. Doktora Tezi (Yayınlanmamış)

Yoldaş, R., Keskin, B., Korkmaz, S., Didik, S.. Kalkan, 1., Ağrıdağ, D.S. ve Besbelli, B. (1985) Samsun ve dolayı (KızılırmakYeşilırmak arasındaki bölgenin) jeolojisi ve petrol olanakları: MTA Rap., 8130 (yayımlanmamış), Ankara. 